\title{
Strategic Map of University Incubation Center
}

\author{
Nahiyah Jaidi Faraz ${ }^{1}$, Setyabudi Indartono ${ }^{2^{*}}$, Siswantoyo ${ }^{3}$, Jane S.C. Liu ${ }^{4}$ \\ ${ }^{123}$ Universitas Negeri Yogyakarta, Indonesia \\ 1nahiyah@uny.ac.id, 2setyabudi_indartono@uny.ac.id, ${ }^{3}$ siswantoyo@uny.ac.id, \\ ${ }^{4}$ Chouyang University of Technology, Taiwan, janeliu@cyut.edu.tw \\ *corresponding author
}

\begin{abstract}
This study is aimed to investigate the Strategic Map of the Incubator center. The business incubation process can vary from one incubator to another. This research extends the previous works to improve the solution business incubator problems in Indonesia heading their competitive advantages heading to the global market compared to the Taiwan cases. This study investigates the different types of business incubator strategies for Indonesia and Taiwan cases by using quantitative and qualitative with the primary that had been collected through surveys and observations. The Result shows that Chaoyang Business Incubation Center (CBIC) and Business Incubator LPPM UNY have quite different patterns of their strategies. The Business Support Model Represent CBIC is program demand: Entrepreneurinitiated, whereas LPPM one is program supply: Incubator-initiated. The Business Incubator LPPM UNY is likely to be more active than BCIC. However, CBIC seems to promote entrepreneurs more actively rather than Business Incubator LPPM UNY.
\end{abstract}

Keywords: Strategic Map, Incubation Center, Indonesia, Taiwan

\section{Peta Strategis Pusat Inkubasi Universitas}

\begin{abstract}
Abstrak
Penelitian ini bertujuan untuk menyelidiki peta strategis dari pusat inkubator. Proses inkubasi bisnis dapat bervariasi dari satu inkubator ke inkubator lainnya. Penelitian ini memperluas karya-karya sebelumnya untuk meningkatkan masalah inkubator bisnis solusi di Indonesia yang mengarah keunggulan kompetitif mereka menuju pasar global dibandingkan dengan kasus Taiwan. Penelitian ini menyelidiki berbagai jenis strategi inkubator bisnis untuk kasus Indonesia dan Taiwan dengan menggunakan kuantitatif dan kualitatif dengan primer yang telah dikumpulkan melalui survei dan observasi. Hasil penelitian menunjukkan bahwa Pusat Inkubasi Bisnis Chaoyang (CBIC) dan inkubator bisnis LPPM UNY memiliki pola strategi mereka yang sangat berbeda. Model pendukung bisnis merupakan CBIC adalah permintaan program: wirausaha dimulai, sedangkan LPPM satu adalah pasokan program: inisiasi inkubator. Inkubator bisnis LPPM UNY kemungkinan akan lebih aktif daripada BCIC. Namun, CBIC tampaknya mempromosikan wirausahawan lebih aktif daripada inkubator bisnis LPPM UNY.
\end{abstract}

Kata kunci: Peta Strategis, pusat Inkubator, Indonesia, Taiwan

\section{INTRODUCTION}

This study is aimed to investigate the Strategic Map of Incubator center in term of the contribution of business incubators to increase quality and quantity of tenant business. It is believed able to increase economic development, new venture creation, and developing countries economic acceleration. Business incubator is found to relate to business funding, technical support, entrepreneurial mentoring, business technology, innovation, and adaptability (Guerrero, Maribel; Urbano, David; Gaj-n, 2017; Jacob, 2017; RibeiroSoriano, 2017; Romein \& Trip, 2017; Xiao \& North, 2017). However, the issue of social 
valuability and effectivity, and business profitability become the challenges for business incubator management to increase both academic and professional entrepreneurship (Allen \& Mccluskey, 1991; Halliday et al., 2016; Rose, 2016; Sentana, Gonzalez, Gasch, \& Llopis, 2017). The Business incubator is likely to be important to drive higher education to strengthen the education process for business. This study investigates the different types of business incubator strategies for Indonesia and Taiwan cases. The incubators steadily increased in number and importance throughout the 1990s, and similar developments are taking place in Thailand, Malaysia and Indonesia (Callegati, Grandi, \& Napier, 2005). Indonesia established three pilot incubators at Serpong, Solo, and Surabaya and continued with more incubators at universities. There were 23 Incubators which were established by universities (72\%), private sector (21\%) and Government (7\%)(Gozali, Masrom, Haron, \& Zagloel, 2015). With the continuing economic and political turmoil in Indonesia, the program is now in jeopardy when it is most needed (Lalkaka, 2001; Soenarso, Nugraha, \& Listyaningrum, 2013). However, few higher educations do not provide business incubation services to their stakeholder. Whereas Taiwan based on their government policy, invested technology incubators and parks which are focus on ICT and biotechnology. They assigned the National Chiao Tung University develop for Small and Medium Enterprise Incubator Centre (Soenarso et al., 2013) (Olaopa \& Siyanbola, 2012).

Business incubators assist emerging ventures by providing support services and assistance in developing their business. The variety of incubating organizations is driven by the evolution of companies' requirements and needs, which encourage incubators to differentiate the range of services that they offer (Grimaldi \& Grandi, 2005; Neck, Meyer, Cohen, \& Corbett, 2004). Thus, the learning and mentoring process of entrepreneurship-as one of identifying an opportunity, creating a team, marshalling resources, and starting the venture. However, the system will thrive only if the environment is conducive for entrepreneurial activity and new venture creation. Many ventures develop in close interaction with each other and with environmental factors such as about infrastructure, public institutions, and about firms that can match together in advanced production systems.

Many business incubators have been growing in Indonesia as well as in Yogyakarta and Central Java. These current incubator agencies need to be mapped to see whether the incubators that have been established, either by government or private institutions, are fulfilling the existing standards. The results of preliminary study showed that 24 respondents of incubator can be mapped into seven incubators at the growing stage, nine incubators at the developing stage, and eight incubators in the mature stage. Some of the programs that were considered supporting the success of tenants such as periodic training and mentoring. Meanwhile, the cause of tenant failure was the weakness of market access. Scholars argued that the common problems encountered in managing business incubators consist of incubating and problems of tenants (Mariani \& Anom, 2020; Ratinho, 2011; Ratinho, Harms, \& Groen, 2010, 2013). The Indonesia and Taiwan model of the Model 
Jurnal Economia, 17(2), October 2021, 284-291

of Business Incubators concept is quite different. Indonesia is likely to Technical Guidance, Partnership, Mentoring and Program Consultation rather than Taiwan that more tend to service on knowledge, financial, an incubation. Furthermore, they applied their strategy to create business incubators and technological and financial support mechanisms in order to maximize opportunities for technology transfer between academic and research facilities and private firms. Based on the result of the strategic implementation, it provides a basis to review and potentially revise the strategy. Hence it is plausible to explore on both Indonesia and Taiwan model of Business Incubators have different type of strategy? How their strategic activities applied on their nature? Accordingly, this study investigates the different strategic map of Indonesia and Taiwan Incubation center.

\section{METHOD}

This study was using quantitative and qualitative with the primary that had been collected through surveys and observations. The use of quantitative methods was intended to reveal facts and information based on survey results and secondary data. Meanwhile, the use of qualitative methods was intended to provide an overview of interview data and observation The study focusses on exploring Type of business incubator strategies for Indonesia and Taiwan. A Qualitative and Quantitative approach be conducted. Qualitative approach is done by Well- developed survey and forum group discussion. A representative Indonesia and Taiwan business incubators are represented by Chaoyang Business Incubation Center (CBIC) and Business Incubator LPPM UNY.

Instrument of this study is developed based on the Balance Scorecard Evaluation, i.e., Business support Model (Program demand: Entrepreneur-initiated Program and Supply: Incubator-initiated). Whereas to explore the Incubators Strategic Activities, we developed 12 items instrument based the equal activities for both parties found in the initial forum group discussion. The instrument has proven by both party expert judgments. The sample used in this study is Chaoyang Business Incubation Center (CBIC) and Business Incubator LPPM UNY which are found to have experience in managing tenants.

\section{FINDING AND DISCUSSION}

Based on the survey and observation on both centers of incubation between Indonesia and Taiwan, it is shown that Chaoyang Business Incubation Center (CBIC) and Business Incubator LPPM UNY have a quite different pattern of their strategies. The Business Support Model Represent CBIC is program demand: Entrepreneur-initiated, whereas LPPM one is program supply: Incubator-initiated. Based on the Balance Scorecard evaluation indicators, the CBIC tends to increase financial statements for Entrepreneurs by using business opportunities and resources access support. However, LPPM UNY uses networking with financial institutions too. The CBIC increases Learning \& Growth for their Entrepreneur by providing training programs/ conferences 
and related programs for linkage and networking, but LPPM UNY by training and guiding programs (Table 1).

Table 1. Balance Scorecard Evaluation

\begin{tabular}{|c|c|c|}
\hline & $\begin{array}{c}\text { Chaoyang Business Incubation } \\
\text { Centre (CBIC) }\end{array}$ & $\begin{array}{c}\text { Business Incubator LPPM } \\
\text { UNY }\end{array}$ \\
\hline $\begin{array}{l}\text { Vision Statement of } \\
\text { Incubator }\end{array}$ & $\begin{array}{l}\text { To be the angel for SMEs and } \\
\text { Startups and the bridge between } \\
\text { CYUT and industries. }\end{array}$ & $\begin{array}{l}\text { Being Superior Business } \\
\text { Incubator in thinking out and } \\
\text { developing technology - } \\
\text { based start-up company } \\
\text { highly competitive Nationally } \\
\text { and Internationally }\end{array}$ \\
\hline $\begin{array}{l}\text { Business } \\
\text { Model }\end{array}$ & $\begin{array}{l}\text { Program demand: Entrepreneur- } \\
\text { initiated }\end{array}$ & $\begin{array}{l}\text { Program Supply: Incubator- } \\
\text { initiated }\end{array}$ \\
\hline Financial statements & $\begin{array}{l}\text { Business opportunities and resources } \\
\text { access support. }\end{array}$ & $\begin{array}{l}\text { Networking with financial } \\
\text { institution }\end{array}$ \\
\hline Learning \& Growth & $\begin{array}{l}\text { Provide training programs/ } \\
\text { conferences and related programs for } \\
\text { linkage and networking. }\end{array}$ & Training and guiding \\
\hline $\begin{array}{l}\text { Internal } \\
\text { Process }\end{array}$ & $\begin{array}{l}\text { Consulting with entrepreneur's case } \\
\text { by case in person. (Mentoring) }\end{array}$ & \\
\hline Customers' Attraction & $\begin{array}{l}\text { Awards pursuing and public report } \\
(\mathrm{PR}) \text { arrangement. (networking) }\end{array}$ & $\begin{array}{l}\text { Advertisement (paper and } \\
\text { electronic media) }\end{array}$ \\
\hline
\end{tabular}

Based on the result of this study (Table 2), the executives of both incubation center strengthened the evidence of the frequencies on this finding. Both centers of the incubator apply strategic activities more than others. The Business Incubator LPPM UNY is likely to be more active rather than BCIC (Table 2). Business Incubator LPPM UNY shows to establish clear metrics for success, develop a rational new- Entrepreneur selection process, Select and monitor application of Entrepreneur services, and Provide financing support more than BCIC. However, BCIC have better activities on Develop and deliver valueadded services to Entrepreneur, ensure that member Entrepreneur gain access to necessary human and financial resources, and provide dynamic, proactive feedback to Entrepreneur rather than The Business Incubator LPPM UNY. Accordingly, CBIC seems to promote entrepreneurs more actively rather than Business Incubator LPPM UNY that shows the role of incubators more than the entrepreneur. It relates to the vision of BCIC that wants to be the angel whereas Incubator LPPM UNY wants to be a Superior Business Incubator 
Jurnal Economia, 17(2), October 2021, 284-291

in thinking out and developing technology. Hence this study validates the model business of those incubation centers, BCIC business support model is developed based on Program demand: Entrepreneur-initiated, and Business Incubator LPPM UNY is developed based on program supply: Incubator-initiated.

Table 2. Strategic Activities

\begin{tabular}{|c|c|c|}
\hline Incubators Strategic Activities & $\begin{array}{l}\text { Chaoyang Business } \\
\text { Incubation Centre } \\
\text { (CBIC) }\end{array}$ & $\begin{array}{c}\text { Business } \\
\text { Incubator } \\
\text { LPPM UNY }\end{array}$ \\
\hline Establish clear metrics for success & often & always \\
\hline Provide entrepreneurial leadership & often & often \\
\hline $\begin{array}{l}\text { Develop and deliver value-added } \\
\text { services to Entrepreneur }\end{array}$ & always & often \\
\hline $\begin{array}{l}\text { Develop a rational new- Entrepreneur } \\
\text { selection process }\end{array}$ & often & always \\
\hline $\begin{array}{l}\text { Ensure that member Entrepreneur gain } \\
\text { access to necessary human and } \\
\text { financial resources }\end{array}$ & always & often \\
\hline Diagnosis of Entrepreneur needs & always & always \\
\hline $\begin{array}{l}\text { Select and monitor application of } \\
\text { Entrepreneur services }\end{array}$ & often & always \\
\hline Provide financing support & sometimes & often \\
\hline Access to the incubator network & always & always \\
\hline $\begin{array}{l}\text { Provide dynamic, proactive feedback to } \\
\text { Entrepreneur }\end{array}$ & always & often \\
\hline $\begin{array}{l}\text { Assist Entrepreneur with business } \\
\text { planning }\end{array}$ & always & always \\
\hline $\begin{array}{l}\text { Encourage Entrepreneur to develop } \\
\text { control systems during the early stage of } \\
\text { incubate development }\end{array}$ & often & often \\
\hline
\end{tabular}

This finding revealed the research question. Indonesia and Taiwan model of Business Incubators is significantly showing the different type of strategy. Their strategic activities applied on their business actions are found contrast. The study is agreed to contribute for both party as well as policy makers to design the regulations stimulating 
appropriate incubator creation that in turn sustain the local entrepreneurship. This study is believed to help policy makers more effectively use business incubators to hatch innovation-based entrepreneurial development. Hence the concept of the adoption of business incubation strategy strengthened the promoting entrepreneurship, stimulating creativity, and facilitating innovation theory.

\section{CONCLUSION}

The study concluded that Chaoyang Business Incubation Center (CBIC) and Business Incubator LPPM UNY have a quite different pattern of their strategies. The Business Support Model Represent CBIC rather to program demand: Entrepreneurinitiated, whereas LPPM one is program supply: Incubator-initiated. Whereas the Business Incubator LPPM UNY is likely to be more active than BCIC. However, CBIC seems to promote entrepreneurs more actively rather than Business Incubator LPPM UNY. Hence, this finding is very important to strengthen the various pattern of strategic map of incubation management.

\section{ACKNOWLEDGEMENT}

The funding of this research project is Daftar Isian Pelaksanaan Anggara (DIPA) LPPM Universitas Negeri Yogyakarta year 2019.

\section{REFERENCES}

Allen, D. N., \& Mccluskey, R. (1991). Structure, Policy, Services, and Performance in the Business Incubator Industry. Entrepreneurship Theory and Practice, 15(2), 61-77. https://doi.org/10.1177/104225879101500207

Callegati, E., Grandi, S., \& Napier, G. (2005). Business Incubation and Venture CapitalAn International Survey on Synergies and Challenges. Joint IPI/IKED Working Paper.

Gozali, L., Masrom, M., Haron, H. N., \& Zagloel, T. Y. M. (2015). A Framework of Successful E-business Incubator for Indonesian Public. 8(2), 120-134.

Grimaldi, R., \& Grandi, A. (2005). Business incubators and new venture creation: An assessment of incubating models. Technovation, 25(2), 111-121. https://doi.org/10.1016/S0166-4972(03)00076-2

Guerrero, Maribel; Urbano, David; Gajen, E. (2017). Higher Education Entrepreneurial Ecosystems: Exploring the Role of Business Incubators in an Emerging Economy. International Review of Entrepreneurship, 15(2), 173-202.

Halliday, M. A. K., Matthiessen, C. M. I. M., Santosa, R., Priyanto, A. D., Nuraeni, A., 
Jurnal Economia, 17(2), October 2021, 284-291

Ellyawati, H. C., Witjaksono, R. W. (2016). Implementasi Sistem Produksi Berbasis Odoo Pada PT. Primarindo Asia Infrastructure Tbk Dengan Metodologi ASAP. EProceedings of Engineering.

Jacob, M. (2017). Entrepreneurships and Startup Programmes: Opportunities in Travel and Tourism. Atna - Journal of Tourism Studies, 12(2), 51-65. https://doi.org/10.12727/ajts.18.3

Lalkaka, R. (2001). Best Practices' in Business Incubation : Lessons ( yet to be ) Learned Rustam Lalkaka Policy \& Business Ecosystem Innovation Entrepreneurship Competitiveness. Human Development, (November), 14-15.

Mariani, W. E., \& Anom, I. G. A. (2020). The Characteristic of Business Incubator Tenant. 400(Icream 2019), 323-326. https://doi.org/10.2991/assehr.k.200130.194

Neck, H. M., Meyer, G. D., Cohen, B., \& Corbett, A. C. (2004). An Entrepreneurial System View of New Venture Creation. Journal of Small Business Management, 42(2), 190-208. https://doi.org/10.1111/j.1540-627x.2004.00105.x

Ratinho, T. (2011). Are they helping? An examination of business incubators' impact on tenant firms. Retrieved from http://doc.utwente.nl/78235/1/thesis_T_Ratinho.pdf

Ratinho, T., Harms, R., \& Groen, A. (2010). Are Business Incubators helping? The role of BIs in facilitating tenants' development. Methodology, 1-35.

Ratinho, T., Harms, R., \& Groen, A. (2013). Business incubators: (How) do they help their tenants? New Technology Based Firms in the New Millennium, 10(October), 161182. https://doi.org/10.1108/S1876-0228(2013)0000010011

Ribeiro-Soriano, D. (2017). Small business and entrepreneurship: their role in economic and social development. Entrepreneurship and Regional Development, 29(1-2), 1-3. https://doi.org/10.1080/08985626.2016.1255438

Romein, A., \& Trip, J. J. (2017). The role of business incubators in the development of sustainable clusters of cultural and creative industries. International Journal of Sustainable Development and Planning, 12(3), 435-445. https://doi.org/10.2495/SDP-V12-N3-435-445

Rose, A. (2016). A multi-stakeholder view on business incubator effectiveness. (November), 130.

Sentana, E., Gonzalez, R., Gasch, J., \& Llopis, J. (2017). The social profitability of business incubators: a measurement proposal. Entrepreneurship and Regional Development, 29(1-2), 116-136. https://doi.org/10.1080/08985626.2016.1255436 
Soenarso, W. S., Nugraha, D., \& Listyaningrum, E. (2013). Development of Science and Technology Park (STP) in Indonesia to Support Innovation-Based Regional Economy: Concept and Early Stage Development. World Technopolis Review, 2(1), 32-42. https://doi.org/10.7165/wtr2013.2.1.32

Xiao, L., \& North, D. (2017). The graduation performance of technology business incubators in China's three tier cities: the role of incubator funding, technical support, and entrepreneurial mentoring. Journal of Technology Transfer, 42(3), 615634. https://doi.org/10.1007/s10961-016-9493-4 